\title{
Passive and active hybrid approach to building design in Saudi Arabia
}

\author{
M. S. Almatawa, A. A. Elmualim \& E. A. Essah \\ School of Construction Management and Engineering, \\ University of Reading, UK
}

\begin{abstract}
The building sector is one of the highest consumers of energy in the world. This has led to high dependency on using fossil fuel to supply energy without due consideration to its environmental impact. Saudi Arabia has been through rapid development accompanied by population growth, which in turn has increased the demand for construction. However, this fast development has been met without considering sustainable building design. General design practices rely on using international design approaches and features without considering the local climate and aspects of traditional passive design. This is by constructing buildings with a large amount of glass fully exposed to solar radiation. The aim of this paper is to investigate the development of sustainability in passive design and vernacular architecture. Furthermore, it compares them with current building in Saudi Arabia in terms of making the most of the climate. Moreover, it will explore the most sustainable renewable energy that can be used to reduce the environmental impact on modern building in Saudi Arabia. This will be carried out using case studies demonstrating the performance of vernacular design in Saudi Arabia and thus its benefits in terms of environmental, economic and social sustainability. It argues that the adoption of a hybrid approach can improve the energy efficiency as well as reduce the carbon footprint of buildings. This is by combining passive design, learning from the vernacular architecture and implementing innovative sustainable technologies.

Keywords: climate, environmental impact, passive design, renewable energy, Saudi Arabia, sustainability, vernacular architecture.
\end{abstract}




\section{Introduction}

The sustainable development becomes a global concern. This is because of different factors such as the growth of population, environmental impact and rapid development in developing countries. According to Mumovic and Santamouris [1] fifty per cent of the world population are living in cities and they expect this to increase to $80 \%$ in rich countries. This would increase the urbanization in the main cities in these countries. Thus, it will lead to an increase in the demand for energy to supply electricity, heating and cooling of buildings. This will significantly produce a large amount of gas emission from various sectors such as transportation, building and industry to the atmosphere.

The sustainable design of buildings in Saudi Arabia identified centuries ago is well embedded within its culture. Moreover, vernacular design in Saudi Arabia and the gulf region features in general, used the available resources and considered the local climate, which is hot and dry [2]. However, the economic development in Saudi Arabia after discovery of oil in 1950 accelerated the development in construction. The rapid development in construction was met without regard for vernacular design in the Kingdom. This is seen by using international design, which utilizes large areas of glass and steel and relies mainly on mechanical systems to provide lighting, heating and cooling [2]. Furthermore, the energy supplies of the buildings depend on the national grid, which uses a conventional process from fossil fuel. At the same time, the application of integrated renewable energy was not considered in the design of buildings despite the high availability of solar radiation that reaches the Saudi land, which is around $7 \mathrm{kwh}$ per square metre [3].

The aim of this paper is to investigate the development of sustainability and use of passive design and vernacular architecture in current building in Saudi Arabia in terms of making the most of the climate. Moreover, it will explore the most sustainable renewable energy that can be harnessed to reduce the environmental impact of modern building in Saudi Arabia.

\section{Vernacular designs in Saudi Arabia}

The vernacular architecture advocates using local resources to meet the local need while reflecting the historical, cultural and climatic consideration [4]. The vernacular design depends on the trial and error method to deal with the local climate [4]. These designs have high flexibility and adaptability even when using new technology and materials [4]. The vernacular design uses different bioclimatic features, which depend on the climatic zone [5]. The main benefits from these features are to have thermal comfort, suitable lighting and air ventilation in the buildings [6].

According to Derya [7] the planning of the vernacular design in the hot and dry climate was not for individual buildings, but for groups of buildings. The specification of these groups required narrow roads between buildings in order to provide more shade, and protected ventilation from the unpleasant outside climate. Another feature of the vernacular design in the hot climate is that it has a 
courtyard in the buildings, which are used for activities and privacy for the occupants. The courtyard would also improve the ventilation system in the whole building. The process helps the warm air to become cold before entrance to the building. In many ways the incoming air is cooled by passing over wet surfaces [6]. In term of materials, the Arabian Peninsula vernacular design was a perfect example of sustainable design. This was achieved by using mud brick, thick walls and palm tree material to provide a more comfortable environment during the high temperature periods $[2,8]$.

However, the literatures point out some negative aspects of the vernacular design such as the lack of aesthetic value and modern style. Abu-Ghazzeh [2] pointed out that the vernacular design should be protected and there is no reason for not adopting this style. This is introduced into the education system in order to advance the sustainability of design in Saudi Arabia. In addition, they argue that there is a lack of information about the efficiency of these designs such as ventilation systems [5]. Janet [9] argues that when the economic factors become more influential than comfort in the building they would take lessons from the vernacular architecture.

In the modern buildings, Aboul Naga and Elsheshtawy [8] found that the amount of energy used for modern buildings is six times higher than the traditional buildings. This is because of the high dependency on artificial cooling systems. These systems have high energy consumption, environmental impact and operation cost. In addition, the large streets and separated buildings that characterised modern buildings have an influence in losing the cultural and social aspects. This can be resolved by considering some essential criteria during the design phase. Derya [7] mentioned that there should be a climate expert during this phase who will analyse the site in terms of renewable energy, air pollution, the location of hazards and climatic features. This would reduce the high dependency on mechanical cooling and heating [4]. Therefore, it would increase the energy efficiency of the buildings while maintaining acceptable thermal comfort for the occupants.

According to Mohammed [10] there is no reason for not adopting traditional building style in Saudi Arabia. This is including using new technologies with modern concepts to have better, and more efficient, control of the indoor climate. Abu-Ghazzeh [2] who clarifies that there is a clear relation between culture and the traditional building in Saudi Arabia showed that the vernacular design in Saudi Arabia had been obtainable. It provides benefits to society in terms of privacy, security and to the built environment in terms of protection of natural resources. He further argues that the reason for moving from traditional design is because of hiring foreign expertise to meet the rapid development within the Kingdom.

\section{Primary energy in Saudi Arabia}

The Kingdom of Saudi Arabia is not only depending heavily on fossil fuel products in its economy but also for supplying energy in the country. The main primary energy production in Saudi Arabia was around 217 TWh in 2009 [11], 
as shown in Figure 1. Figure 2 shows the total energy production from oil and gas in 2009. In 2009, Saudi Arabia was classified as the largest consumer of oil in the world in order to supply energy locally with a consumption level reaching 120 TWh (around 73 million barrels per year) [11].

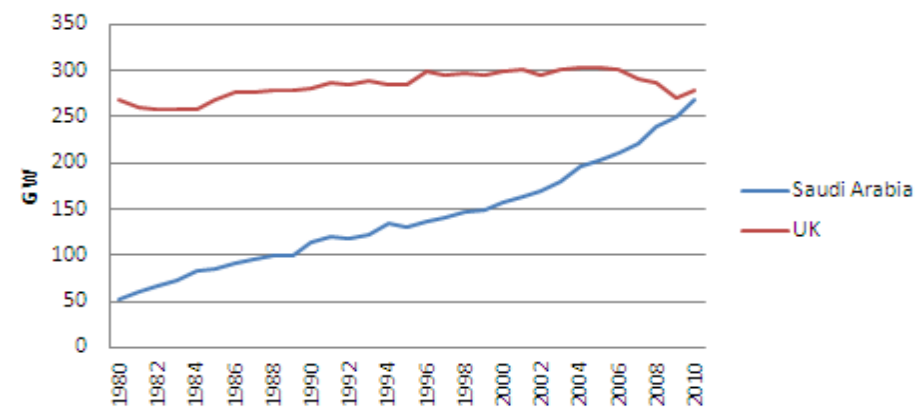

Figure 1: The primary energy consumption in Saudi Arabia and United Kingdom (1980-2010).

The total primary energy produced is $217 \mathrm{TWh}$

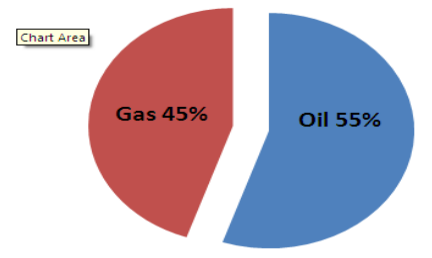

Figure 2: $\quad$ Primary energy production in Saudi Arabia 2009 [11].

In addition, the total energy consumption is approximately $183 \mathrm{TWh}$ per year. This is depending on each sector in Saudi Arabia such as residential, commercial, industrial and agriculture as shown in Figure 3. The figure shows that the commercial buildings are consuming about 30 per cent of energy.

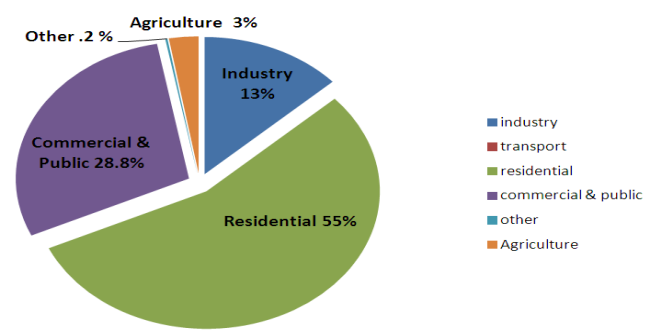

Figure 3: $\quad$ The consumed energy by sector in 2009 in KSA [11]. 
There are several challenges facing the energy sector in Saudi Arabia. The high growth rate in Saudi Arabia is around 3 per cent per year. In spite of this, there are some arguments that this number would be decreased, as the females would have more jobs opportunity [12]. If it remains constant at this rate, the population in 2050 will be more than double. In addition, the carbon emission produced from supplying this energy is extremely high which is estimated at 550 million tonnes of carbon dioxide as shown in Figure 4. The joining of international organizations such as climate change, and the climate changeKyoto protocol will increase the pressure to reduce the emission and sustain the development in the country.

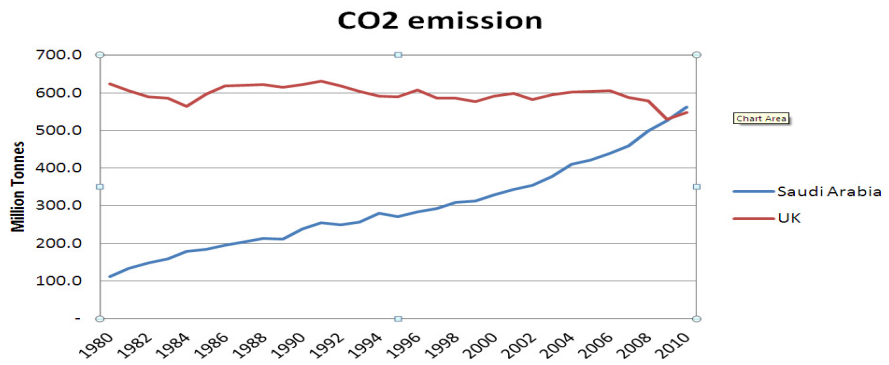

Figure 4: $\quad$ The $\mathrm{CO}_{2}$ emission for KSA and United Kingdom (1980-2010).

\subsection{The application of renewable energy in Saudi Arabia}

Saudi Arabia has realized the potential of renewable energy to reduce the dependency on fossil fuel in supplying energy [13]. The Government has commissioned some research and development in these fields. The majority has been conducted in King Abdulaziz City for Science and Technology (KACST) projects. In addition, there are some joint ventures in the research and development between the Energy Research Institute (ERI) at KACST and SOLERAS from the United States and HYSOLAR from Germany [13]. The projects have been developed by ERI as summarized in Table 1. The aims of these projects are to supply energy to the rural areas that are not connected to the national grid and for lighting in the mountain areas [14]. Moreover, photovoltaic (PV) technology is used to produce potable water in the desalination plants or to pump it from the ground water.

The projects, which are undertaken by KACST in renewable energy, have been contributing to understanding the performance of these technologies within the Saudi Arabia climate. However, the energy output for some of them has decreased, and others have been eliminated [14]. The Solar Village project is located in the hot desert climate outside Riyadh, the capital city of the Kingdom. The efficiency of the PV used is given in the range of 8 to 11 per cent. The PV system was operating positively in the 15 years but the output is reduced by 20 per cent with an annual failure of 2.6 per cent [13]. This is due to the process of cooling the cells by using the heat sink assembly. This was not efficient for this 
Table 1: $\quad$ Renewable energy project controlled by KACST [14].

\begin{tabular}{|c|c|c|c|}
\hline Projects & Location & Duration & Applications \\
\hline $350 \mathrm{~kW}$ PV system (2155 MWh) & Solar Village & $1981-87$ & $\begin{array}{l}\text { AC/DC electricity for remote } \\
\text { areas }\end{array}$ \\
\hline $\begin{array}{l}350 \mathrm{~kW} \text { PV hydrogen production } \\
\text { plant (1.6 MWh) }\end{array}$ & Solar Village & $1987-93$ & $\begin{array}{l}\text { Demonstration plant for solar } \\
\text { hydrogen production }\end{array}$ \\
\hline Solar cooling & $\begin{array}{l}\text { Saudi } \\
\text { universities }\end{array}$ & $1981-87$ & $\begin{array}{l}\text { Developing of solar cooling } \\
\text { laboratory }\end{array}$ \\
\hline $\begin{array}{l}1 \mathrm{~kW} \text { solar hydrogen generator } \\
(20-30 \mathrm{kWh})\end{array}$ & Solar Village & $1989-93$ & $\begin{array}{l}\text { Hydrogen production, testing and } \\
\text { measurement (laboratory scale) }\end{array}$ \\
\hline $2 \mathrm{~kW}$ solar hydrogen $(50 \mathrm{kWh})$ & KAU, Jeddah & $1986-91$ & $\begin{array}{l}\text { Testing of different electrode } \\
\text { materials for solar hydrogen } \\
\text { plant }\end{array}$ \\
\hline $3 \mathrm{~kW} \mathrm{PV} \mathrm{test} \mathrm{system}$ & Solar Village & $1987-90$ & Demonstration of climatic effects \\
\hline $4 \mathrm{~kW}$ PV system & $\begin{array}{l}\text { Southern } \\
\text { regions of Saudi } \\
\text { Arabia }\end{array}$ & 1996 & $\begin{array}{l}\text { AC/DC electricity for remote } \\
\text { areas }\end{array}$ \\
\hline $\begin{array}{l}6 \mathrm{~kW} \text { PV system } \\
\text { Solar seawater desalination }\end{array}$ & Solar Village & $1996-98$ & PV grid connection \\
\hline $\begin{array}{l}\text { PV water desalination }\left(0.6 \mathrm{~m}^{3}\right. \\
\text { per hour })\end{array}$ & Sadous Village & 1994-99 & $\mathrm{PV} / \mathrm{RO}$ interface \\
\hline Solar-thermal desalination & Solar Village & $1996-97$ & $\begin{array}{l}\text { Solar distillation of brackish } \\
\text { water }\end{array}$ \\
\hline $\mathrm{PV}$ in agriculture $(4 \mathrm{kWp})$ & Muzahmia & 1996 & AC/DC grid connected \\
\hline $\begin{array}{l}\text { Long-term performance of PV ( } 3 \\
\mathrm{~kW})\end{array}$ & Solar Village & Since 1990 & Performance evaluation \\
\hline $\begin{array}{l}\text { Fuel cell development }(100-1000 \\
\text { W) }\end{array}$ & Solar Village & $1993-2000$ & Hydrogen utilization \\
\hline Internal combustion engine (ICE) & Solar Village & $1993-95$ & Hydrogen utilization \\
\hline Solar radiation measurement & 12 stations & 1994-2000 & Saudi solar atlas \\
\hline Wind energy measurement & 5 stations & $1994-2000$ & Saudi solar atlas \\
\hline Solar dryers & A1-Hassa, Qatif & $1988-93$ & $\begin{array}{l}\text { Food dryers (dates, vegetables, } \\
\text { etc.) }\end{array}$ \\
\hline $\begin{array}{l}\text { Two solar-thermal dishes (50 } \\
\text { kW) }\end{array}$ & Solar Village & $1986-94$ & Advanced solar stirling engine \\
\hline Energy management in buildings & Dammam & $1988-93$ & Energy conservation \\
\hline Solar colletors development & Solar Village & $1993-97$ & Domestic, industrial, agricultural \\
\hline Solar refrigeration & Solar Village & 1999-2000 & Desert application \\
\hline
\end{tabular}

climate, which caused some models to fail and change their colour to brown. In addition there were short circuit problems and water impact in the models [14]. Another negative aspect is the failure for non-photovoltaic materials such as membranes. For example, the desalination project was closed for this reason, classifying the project as uneconomic. In addition, one of the difficulties is maintaining and cleaning the PV, especially in high mountain areas involving unskilled workers. According to Alawaji [13], when the panel has accumulated dust and dirt the efficiency will reduce by 2.5 per cent per month and this will require water for cleaning.

In the construction industry, there are several initiatives focusing on developing green building design in Saudi Arabia. This is to reduce the carbon emissions and increase the energy efficiency by adopting new technologies. King Abdullah University for Science and Technology (KAUST) campus have integrated the buildings by adopting sustainable practices. They install high performance roofs using hybrid technologies, such as photovoltaic and solar thermal equipment to generate heat and electricity as shown in Figure 5. This system has been installed in 900,000 square feet of roofs, and it estimates to meet 8 per cent of the whole campus demand for energy [15]. Other features in this project include constructing a high solar tower for passive cooling. In this tower, fans are installed to meet the different pressures as shown in Figures 5-6 [15]. The tower has high performance glazing that filters daylight and reduces the use of artificial lighting. This project is the first building that has a platinum LEED certificate in Saudi Arabia [16]. 

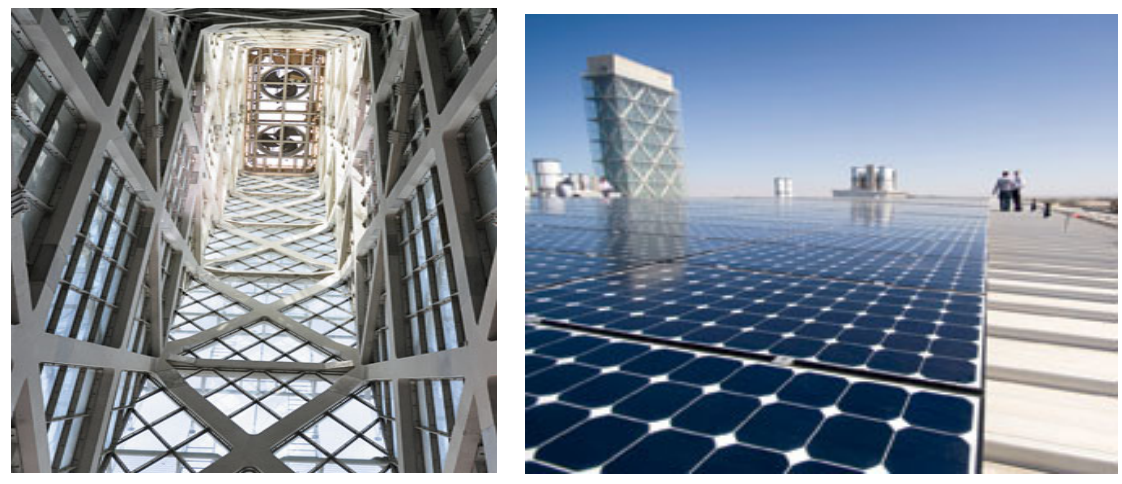

Figure 5: $\quad$ The solar tower and the top roof at KAUST [15].

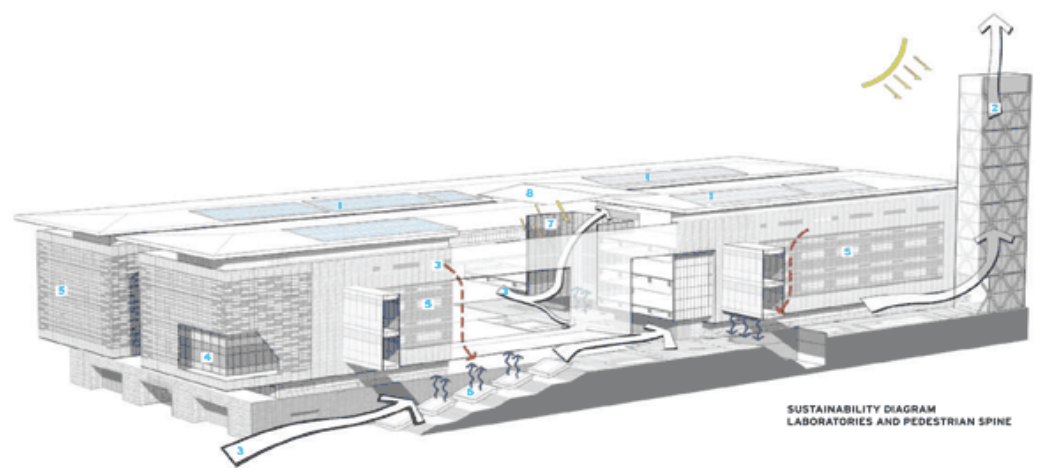

Figure 6: The overview of the ventilation system at KAUST [15].

Furthermore, the north park tower project in Khobar, which was completed in 2011, has integrated the building with renewable energy. This is achieved by installing the photovoltaic panel in the car park, which is around 17 hectares (17000 square metres). This would be generating the complete energy demand for the building which is around $10 \mathrm{MW}$ and the panels would provide the shading needed for cars as shown in Figure 7 [3].

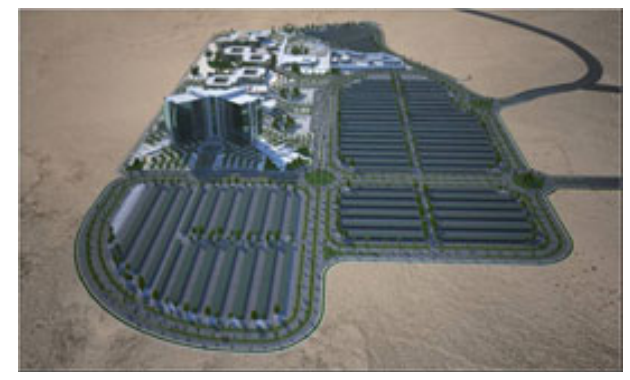

Figure 7: $\quad$ The north park tower project [3]. 
This demonstrates that there is a contribution towards sustainable development especially in the field of supplying energy. However, this progress is still needed in order to improve the energy consumption produced from fossil fuel and to sustain the growth in the country.

\subsection{Sustainable and energy efficiency in Saudi Arabia}

The advantages of using renewable energy are not only for the environment but also for the society. Alnatheer [17] stated that the application of these technologies will not only reduce the environmental impact and secure the energy in Saudi Arabia but they would also create new markets, which would increase the availability of jobs in the country.

However, there are several barriers to integrating a building with renewable energy in the Gulf Country Council (GCC) in general and Saudi Arabia in particular. As mentioned by Taleb and Pitts [18], the obstacles to implementation of PVs in the GCC include the lack of public awareness of the environmental benefits of using this technology. The cheap electricity supplies from the conventional process in the region depend on fossil fuel. In addition, there is a lack of information available on the performance of renewable energy technologies and their economic benefits. Furthermore, they point out that the most significant challenge of these technologies is the public acceptance; especially there are issues regarding solar energy education in Saudi Arabia. Moreover, according to Alnaser and Flanagan [19] there is a lack of strategy in sustainable building in the GCC, which could cause an energy crisis and harm the environment. They mentioned the decision makers in the GCC who claim that the renewable energy would only be economic in rural areas, which are not on the national grid [19]. Furthermore, According to Taleb and Sharples [20] the energy efficiency is not being considered seriously in buildings in Saudi Arabia. They observed that the designs of buildings in this region are not taking into account the harsh climate and application of new technologies in the buildings. They argue correctly that the reasons for this are in not using high thermal mass materials, and not improving the insulation for buildings and the lack of regulations. Moreover, in spite of the environmental benefit of installing photovoltaic panels in buildings it is not economical to use them without Government incentive because of the high cost [20]. In addition, there is a lack of familiarity and information from the involved parties, users and Government decision makers in Saudi Arabia that the application of renewable energy has economic advantages [17]. Huraib et al. [14] argues that there should be support from the Government as with the oil sector to the solar energy, which can only be adopted by incentive strategy.

\section{Research method}

A state-of-the-art literature review on vernacular design in Saudi Arabia and sustainable practice was conducted to evaluate energy efficiency in buildings. In addition, the literature review included the challenge for implementation of 
renewable energy in Saudi Arabia particularly when integrated into buildings. Interviews with six experts in these fields with open-ended questions were conducted including designers, contractors, investors and scholars who are involved in this industry in Saudi Arabia. According to Haigh [21] the interview can potentially be a strong method for assessment and collecting in-depth data before using another approach. The interview schedule discusses the aspects of traditional building and modern design in Saudi Arabia; and in addition, the factors that influence adopting and realizing the potential of vernacular design. This will help to identify the barriers of integrating the building with renewable energy. In addition the interviews approach will enable this research to narrow the scope of the overall research project.

The interview schedule includes the following leading questions:

- To what extent the tradition buildings in Saudi Arabia are sustainable in terms of social, economic and environmental factors.

- To what extent the modern building in Saudi Arabia employs sustainable practices.

- The barriers for integrating innovative sustainable technologies in Saudi Arabian buildings.

\section{Interview analyses}

This section would analyse the respondents' views on the sustainable practice of the modern building and traditional building in Saudi Arabia. In addition, it would identify the barriers of adopting the renewable energy technology. The interviewees' backgrounds are: three architects, two researchers and an engineer. The data show that, from five of the interviewees, the majority of modern buildings in Saudi Arabia do not have any sustainable practices. The engineer comments that there is a lack in the regulation and codes of the buildings in Saudi Arabia. They have not been updated for decades in terms of environmental assessment or energy efficiency. This interviewee added that some individual decision makers are engaging in sustainability and green building. However, they face difficulty in creating environmental buildings. This is because in the quest for best practice to be integrated into renewable and passive design the cost of projects would be greatly increased and organizations would not make a profit. However, there is an initiative from the Saudi Electricity Company to increase the efficiency of buildings in order to reduce the energy consumption by improving the insulation of the building envelopes. Another architectural designer points out that the owners of the buildings look for specifications, which are not suitable for the Saudi Arabia climate in terms of materials. The participants added that public awareness is particularly valuable. This is because the initial cost of the green building is high and the majority are not concerned if the building has LEED certification or not; they would make the decision based on the cost.

In terms of the traditional building in Saudi Arabia, the participants agreed that it has been built using local materials and taking advantage of the climate in terms of natural lighting and ventilation in that time. However, two of the 
respondents mention that these buildings have certain limits to the ideas that can contribute in the buildings at this period. In addition, one of the interviewees, who is a specialist in maintaining the traditional building, says that there are many lessons that have been learned from these buildings. Furthermore, there are also many who did not discover that this is because these buildings are responding positively to the local climate and this is healthier for the occupiers.

In terms of renewable energy, three of the interviewees believed that Saudi Arabia can take advantage of the renewable energy like solar power and in some places for wind and geothermal energy. However, they mention the challenge of adopting these technologies. From a project manager's view the installing of photovoltaic cells needs complicated processes and professional knowledge to increase the performance. It also has low energy efficiency, which is around 16 per cent and that means to produce some useful amount from the panels would need a large area. Another points out that this technology would require more time for studying the geographic location and the performance such as the geothermal technology. They argue that it could be considered when the efficiency increases, which in turn would reduce the required area. However, the researcher points out that the photovoltaic technologies have been developed and especially with the nanotechnology it would be improved and the efficiency could reach 40 per cent or more. The availability of materials to manufacture the panels, such as silicon, in Saudi Arabia can offer the country economic opportunities. The challenges facing the country are the social issues, which are the public awareness of the principle of sustainability, climate change and new technology with a low carbon footprint. In addition, there is the issue of cleaning these panels, in which it is suggested finding a material for cleaning with less use of water to save the natural resource in Saudi Arabia.

\section{Conclusion}

Sustainable development can be achieved by combining various architectural approaches. The adoption of passive design and learning from the vernacular design can improve the energy efficiency with better quality of internal environments. This paper has represented some features of the vernacular design in Saudi Arabia. Furthermore, the performance of the renewable energy in Saudi Arabia was reviewed using previous projects as case studies. However, to advance sustainable buildings, research on the performance of the vernacular design is needed. Moreover, the cultural awareness of the advantages of these buildings in terms of ventilation and natural lighting should be adequately investigated and fully published. There is a need for raising public awareness to change their behaviour. In addition, building regulations are needed in order to reduce the energy consumption. This can be achieved by using a hybrid approach that seeks to integrate aspects of vernacular design with sustainable modern technologies. This would address the issues of these buildings in Saudi Arabia and hence advance the application of sustainable practice in Saudi Arabia by hybrid designs combining passive and active innovative sustainable technologies. 


\section{References}

[1] Mumovic, D. and Santamouris, M., A handbook of sustainable building design and engineering : an integrated approach to energy, health and operational performance London, Earthscan, 2009.

[2] Abu-Ghazzeh, T. M., 'Vernacular architecture education in the Islamic society of Saudi Arabia: Towards the development of an authentic contemporary built environment'. Habitat International, 21, 229-253, 1997.

[3] ARAMCO. Solar program with Solar Frontier. [Online] http://www.saudiaramco.com

[4] Radhakrishnan, S. P., Sundarraja, M. C. and Radhakrishna, S., 'Solar passive techniques in the vernacular buildings of coastal regions in Nagapattinam, TamilNadu-India-a qualitative and quantitative analysis'. Energy and Buildings, 2011.

[5] Singh, M. K., Mahapatra, S. and Atreya, S. K., 'Solar passive features in vernacular architecture of North-East India'. Solar Energy, 85, 2011-2022, 2011.

[6] Omer, A. M., 'Renewable building energy systems and passive human comfort solutions'. Renewable and Sustainable Energy Reviews, 12, 1562$1587,2008$.

[7] Derya, O., 'Design with the climate in housing environments: an analysis in Northern Cyprus'. Building and Environment, 37, 1003-1012, 2002.

[8] Aboul Naga, M. M. and Elsheshtawy, Y. H., 'Environmental sustainability assessment of buildings in hot climates: the case of the UAE'. Renewable Energy, 24, 553-563, 2001.

[9] Janet, R., 'Coal fires, fresh air and the hardy British: A historical view of domestic energy efficiency and thermal comfort in Britain'. Energy Policy, 2011.

[10] Mohammed A. E. S., 'The Integration of Tradition and Modernity: A Search for an Urban and Architectural Identity in Arriyadh, The Capital of Saudi Arabia'. Habitat International, 22, 571-589, 1998.

[11] International energy agency (IEA). Key world energy statistics, [Online]. http://www.iea.org/publications/freepublications/publication/key world en ergy stats-1.pdf

[12] Al-Saleh, Y., 'Renewable energy scenarios for major oil-producing nations: The case of Saudi Arabia'. Futures, 41, 650-662, 2009.

[13] Alawaji, S. H., 'Evaluation of solar energy research and its applications in Saudi Arabia: 20 years of experience'. Renewable and Sustainable Energy Reviews, 5, 59-77, 2001.

[14] Huraib, F. S., Hasnain, S. M. and Alawaji, S. H., 'Lessons learned from solar energy projects in Saudi Arabia'. Renewable Energy, 9, 1144-1147, 1996.

[15] [Minutillo, J., Architectural record. America, 2010.

[16] KAUST. Sustinable site planning. [Online] http://www.kaust.edu.sa/

[17] Alnatheer, O., 'The potential contribution of renewable energy to electricity supply in Saudi Arabia'. Energy Policy, 33, 2298-2312, 2005. 
[18] Taleb, H. M. and Pitts, A. C., 'The potential to exploit use of buildingintegrated photovoltaics in countries of the Gulf Cooperation Council'. Renewable Energy, 34, 1092-1099, 2009.

[19] Alnaser, N. W. and Flanagan, R., 'The need of sustainable buildings construction in the Kingdom of Bahrain'. Building and Environment, 42, 495-506, 2007.

[20] Taleb, H. M. and Sharples, S., 'Developing sustainable residential buildings in Saudi Arabia: A case study'. Applied Energy, 88, 383-391, 2011.

[21] Haigh, R., 'Interviews: A Negotiated Parternship'. Advanced research methods in the built environment, eds. Knight, A. and Ruddock, L. John Wiley and Sons Ltd: Oxford, 2008. 